\title{
SKRINING DAN PENGENDALIAN FAKTOR RISIKO IBU HAMIL DENGAN PELAYANAN ANTENATAL CARE TERPADU DI WILAYAH KERJA PUSKESMAS KECAMATAN MUARA KABUPATEN TAPANULI UTARA
}

\author{
Juana Linda Simbolon ${ }^{1 *}$; Sulastry Pakpahan ${ }^{2}$ \\ ${ }^{1}$ Prodi Kebidanan Tarutung, Poltekkes Kemenkes Medan \\ ${ }^{2}$ Prodi Kebidanan Tarutung, Poltekkes Kemenkes Medan \\ *Korespondensi: mamado_kia2005@yahoo.com
}

\begin{abstract}
Background: The maternal mortality rate (MMR) in Indonesia is still quite high, based on the results of SUPAS in 2015, the MMR was 305/ 100,000 live births. Efforts to decrease of MMR can be done by ensuring that every mother can access quality health services for pregnant women because every pregnancy has the risk of complications. Integrated antenatal services are carried out including health counseling, antenatal care, case management and follow-up, preparation for delivery and planning for referrals in case of pregnancy. In the initial research conducted in Hutaginjang Village, Muara, there were still pregnant women who did not have their pregnancy checked according to the minimum pregnancy standards. Purpose: Screening and pregnancy risk factors is indispensable for early pregnancy and the potential for emergency pregnancy. Methods: Activities carried out by integrated and free pregnancy examinations for pregnant women include measuring weight / height and arm circumference, vital signs, physical examination, Hb examination, urine protein and glucose, provision of IEC about nutritional fulfillment, overcoming complaints of pregnant women in trimester IIII, preparation for delivery and administration of iron supplements as well as preparation for referrals for mothers who experience complications in their pregnancy. Results: The activity was carried out without any obstacles, with 18 mothers having their pregnancies checked. The results of the examination found several risk factors for pregnancy, namely age under 20 years and above 35 years of parity, history of delivery by sectio, height below $145 \mathrm{~cm}$, anemia, preeclampsia, breech location, hyperemesia gravidarum, gestational diabetes and gemelli pregnancy. Each mother received communication, information and education related to maintaining and improving health during pregnancy and giving iron tablets. Conclusion:

Screening and control of pregnancy risk factors is needed to detect early whether the pregnancy is at risk and has the potential for emergency pregnancy, so that the mother can pass her pregnancy well and give birth to a healthy baby.
\end{abstract}

Keywords: Pregnancy, Risk Factors, Screening 


\begin{abstract}
ABSTRAK
Latar belakang: Angka kematian ibu (AKI) di Indonesia masih cukup tinggi, berdasarkan hasil SUPAS pada tahun 2015 diperoleh AKI sebanyak 305/100.000 kelahiran hidup. Upaya percepatan penurunan AKI dapat dilakukan diantaranya dengan menjamin agar setiap ibu dapat mengakses pelayanan kesehatan ibu hamil yang berkualitas karena setiap kehamilan mempunyai resiko mengalami pernyulit atau komplikasi. Pelayanan antenatal terpadu dilaksanakan meliputi konseling kesehatan, pemeriksaan kehamilan, penanganan dan tindak lanjut kasus, persiapan persalinan dan perencanaan rujukan jika terjadi komplikasi kehamilan. Penelurusan awal yang dilakukan di Desa Hutaginjang, Muara masih terdapat ibu hamil tidak memeriksakan kehamilannya sesuai dengan standart minimal kunjungan kehamilan. Tujuan: Skrining dan pengendalian faktor risiko kehamilan sangat diperlukan untuk mendeteksi secara dini kehamilan berisiko dan potensial mengalami kegawatdaruratan kehamilan.

Metode: Kegiatan dilakukan dengan pemeriksaan kehamilan secara terpadu dan gratis kepada ibu hamil meliputi pengukuran BB/TB dan LiLA, tanda-tanda vital, pemeriksaan fisik, pemeriksaan $\mathrm{Hb}$, protein dan glukosa urine, pemberian KIE tentang pemenuhan nutrisi, mengatasi keluhan ibu hamil trimester I-III, persiapan persalinan dan pemberian suplemen zat besi serta persiapan rujukan bagi ibu yang mengalami komplikasi pada kehamilannya.

Hasil: Pelaksanaan kegiatan berlangsung tanpa kendala, jumlah ibu yang memeriksakan kehamilannya 18 orang. Hasil pemeriksaan ditemukan beberapa faktor risiko kehamilan yaitu umur di bawah 20 tahun dan diatas 35 tahun paritas, riwayat persalinan sectio secarea, tinggi badan dibawah $145 \mathrm{~cm}$, anemia, preeklampsi, letak sungsang, hyperemesia gravidarum, diabetes gestasional dan kehamilan gemelli. Masing-masing ibu mendapat komunikasi, informasi dan edukasi terkait menjaga dan meningkatkan kesehatan selama kehamilan serta pemberian tablet zat besi.

Simpulan: Skrining dan pengendalian faktor risiko kehamilan sangat diperlukan untuk mendeteksi secara dini apakah kehamilannya berisiko dan potensial mengalami kegawatdaruratan kehamilan, sehingga ibu dapat melewati masa kehamilannya dengan baik dan melahirkan bayi yang sehat
\end{abstract}

Kata kunci: Faktor Risiko, Kehamilan, Skrining

\title{
PENDAHULUAN
}

Angka kematian ibu (AKI) merupakan salah satu indikator keberhasilan upaya kesehatan ibu. AKI adalah jumlah kematian ibu selama masa kehamilan, persalinan dan nifas yang disebabkan oleh kehamilan, persalinan, dan nifas atau pengelolaannya tetapi bukan karena sebab-sebab lain seperti kecelakaan atau terjatuh di setiap 100.000 kelahiran hidup.(Prawirohardjo, 2016) Berdasarkan hasil SUPAS pada tahun 2015 diperoleh AKI di Indonesia sebanyak 305/100.000 
kelahiran hidup. Upaya percepatan penurunan AKI dapat dilakukan dengan menjamin agar setiap ibu dapat mengakses pelayanan kesehatan ibu yang berkualitas, seperti pelayanan kesehatan ibu hamil, pertolongan persalinan oleh tenaga kesehatan terlatih di fasilitas pelayanan kesehatan, perawatan pasca persalinan bagi ibu dan bayi, perawatan khusus dan rujukan jika terjadi komplikasi. (Kemenkes RI, 2018).

Setiap kehamilan, dalam perkembangannya mempunyai resiko mengalami pernyulit atau komplikasi. Mengingat banyaknya kondisi yang dapat dikaitkan dengan kehamilan risiko tinggi maka setiap ibu hamil perlu mendapat pelayanan antenatal untuk mempersiapkan kehamilan dengan baik agar kondisi yang berpotensi menimbulkan risiko atau penyulit komplikasi kehamilan dapat diketahui dan ditangani secepatnya.

Pemeriksaan antenatal pada $i$ bu hamil dianjurkan dengan memenuhi frekuensi minimal di tiap trimester, yaitu minimal satu kali pada trimester pertama (usia kehamilan 0-12 minggu), minimal satu kali pada trimester kedua (usia kehamilan 12-24 minggu), dan minimal dua kali pada trimester ketiga (usia kehamilan 24 minggu sampai persalinan). Standar waktu pelayanan tersebut dianjurkan untuk menjamin perlindungan terhadap ibu hamil dan atau janin berupa deteksi dini faktor risiko, pencegahan, dan penanganan dini komplikasi kehamilan.(Kemenkes RI, 2014)

Pelayanan antenatal terpadu atau terintegrasi merupakan integrasi pelayanan antenatal rutin dengan beberapa program lain yang sasarannya pada ibu hamil, yang dilaksanakan untuk meningkatkan kualitas pelayanan antenatal. Dalam pelayanan antenatal terintegrasi, tenaga kesehatan harus dapat memastikan bahwa kehamilan berlangsung normal, mampu mendeteksi dini masalah dan penyakit yang dialami ibu hamil, melakukan intervensi secara adekuat sehingga ibu hamil siap untuk menjalani persalinan normal. (Kemenkes RI, 2014). Pelayanan antenatal terpadu dilaksanakan meliputi konseling kesehatan, pemeriksaan kehamilan untuk skrining masalah, penyakit dan komplikasi kehamilan, penanganan dan tindak lanjut kasus, persiapan persalinan dan perencanaan/ antisipasi untuk melakukan rujukan jika terjadi komplikasi kehamilan. Kualitas 
pelayanan antenatal yang diberikan akan mempengaruhi kesehatan ibu hamil dan janinnya, ibu bersalin, bayi baru lahir serta ibu nifas untuk mewujudkan generasi yang berkualitas

Penelurusan awal yang dilakukan di Desa Hutaginjang, Kecamatan Muara masih ada sebagian ibu hamil tidak memeriksakan kehamilannya sesuai dengan standart minimal kunjungan kehamilan karena berbagai alasan. Skrining dan pengendalian faktor risiko kehamilan sangat diperlukan untuk mendeteksi secara dini apakah kehamilannya berisiko dan potensial mengalami kegawatdaruratan kehamilan, dengan demikian ibu dapat melewati masa kehamilannya dengan baik dan menghasilkan bayi yang sehat.

\section{METODE}

Kegiatan yang dilakukan untuk skrining dan pengendalian faktor risiko kehamilan adalah melakukan pemeriksaan kehamilan secara terpadu dan gratis kepada ibu hamil meliputi pengukuran BB/TB dan Lingkar lengan atas (LiLA, tanda-tanda vital, pemeriksaan fisik, pemeriksaan kadar $\mathrm{Hb}$, protein dan glukosa urine), pemberian KIE tentang pemenuhan nutrisi, pencegahan anemia, mengatasi keluhan ibu hamil trimester I-III, persiapan persalinan dan pemberian suplemen zat besi serta persiapan rujukan bagi ibu yang mengalami komplikasi pada kehamilannya.

\section{HASIL DAN PEMBAHASAN}

Kegiatan ini dilaksanakan di desa Hutaginjang, Muara, Kabupaten Tapanuli Utara pada tanggal 9-10 April 2018. Pelaksanaan kegiatan bekerjasama dengan Puskesmas Muara melalui bidan desa Hutaginjang dan dibantu oleh mahasiswa kebidanan Prodi Tarutung. Jumlah ibu hamil yang datang untuk pemeriksaan sebanyak 18 orang. Hasil pemeriksaan kehamilan yang dilakukan diraikan pada tabel berikut ini: 
Tabel 1. Karakteristik ibu hamil di Desa Hutaginjang, Muara

\begin{tabular}{llcc}
\hline & Kategori & Frekuensi & Persentase \\
\hline Umur & $<20$ tahun & 2 & 11,1 \\
& $20-35$ tahun & 11 & 61,1 \\
\multirow{4}{*}{ Paritas } & $>35$ tahun & 5 & 27,8 \\
& Jumlah & 18 & 100 \\
& Primigravida & 5 & 27,8 \\
Pendidikan & Multigravida & 13 & 72,2 \\
& Jumlah & 18 & 100 \\
& Dasar & 6 & 33,3 \\
& Menengah & 9 & 50 \\
Pekerjaan & Perguruan tinggi & 3 & 16,5 \\
& Jumlah & 18 & 100 \\
& Petani & 10 & 55,5 \\
& Wiraswasta & 5 & 27,8 \\
& Pegawai swasta & 1 & 5,5 \\
Riwayat & ASN & 2 & 11,1 \\
persalinan & Jumlah & 18 & 100 \\
& Normal & 13 & 72,2 \\
Tinggi badan & Sectio secarea & 5 & 27,8 \\
& Jumlah & 18 & 100 \\
& $<145$ cm & 2 & 11,1 \\
& $>145$ cm & 16 & 88,9 \\
& Jumlah & 18 & 100 \\
\hline
\end{tabular}

Sumber: Pengabdian kepada masyarakat tahun 2018

Kehamilan pada ibu berusia di bawah 20 tahun dan diatas 35 tahun mempunyai risiko komplikasi yang lebih besar dibandingkan usia 20-35 tahun. Risiko umur dibawah 20 tahun secara biologis belum optimal karena faktor mental dan emosional masih labil sehingga mengakibatkan kurangnya perhatian terhadap pemenuhan nutrisi selama kehamilan. Risiko keguguran dan kelainan genetik semakin meningkat pada usia diatas 40 tahun. Paritas yang terlalu banyak akan mengurangi kesempatan ibu untuk memulihkan kondisi tubuh dan mengembalikan zat gizi yang terpakai selama kehamilan sebelumnya. Risiko komplikasi persalinan meningkat mulai dari persalinan ketiga dan seterusnya. Wanita dengan tinggi badan di bawah $145 \mathrm{~cm}$ lebih mungkin mengalami panggul kecil yang akan mempersulit proses persalinan secara normal. Kehamilan berisiko tinggi juga dipengaruhi oleh riwayat kehamilan dan persalinan ibu sebelumnya. 
Tabel 2. Status anemia ibu berdasarkan hasil pemeriksaan kadar $\mathbf{H b}$

\begin{tabular}{lcc}
\hline \multicolumn{1}{c}{ Status anemia } & Frekuensi & Persentase \\
\hline Tidak anemia & 5 & 27,8 \\
Anemia ringan $(9-10 \mathrm{gr} \%)$ & 10 & 55,7 \\
Anemia sedang $(7-8 \mathrm{gr} \%)$ & 3 & 16,5 \\
Anemia berat $(<7 \mathrm{gr} \%)$ & 0 & 0 \\
Total & 18 & 100 \\
\hline
\end{tabular}

Sumber: Pengabdian kepada masyarakat tahun 2018

Kebutuhan zat besi pada ibu hamil meningkat yang digunakan untuk pertumbuhan fetus, plasenta, jaringan uterus, payudara dan peningkatan voluem darah. Kebutuhan tambahan zat besi yang diperlukan sekitar 800-1000 mg. Apabila kebutuhan ini tidak terpenuhi maka ibu dapat mengami anemia. Anemia pada kehamilan merupakan kondisi ibu dengan kadar $\mathrm{Hb}$ dalam darahnya kurang dari $11 \mathrm{gr} \%$, hal ini dapat mengakibatkan dampak yang membahayakan ibu dan janinnya. Bila terjadi sejak awal kehamilan dapat meningkatkan persalinan prematur, abortus dan pada saat persalinan dapat terjadi perdarahan post partum dan atonia uteri. (Manuaba, IBG, 2014)

Pemberian tablet zat besi (Fe sulfat $320 \mathrm{mg}$ dan asam folat $0,5 \mathrm{mg}$ ) merupakan salah satu alternatif mencegah anemia pada kehamilan, dianjurkan dikonsumsi selama 90 hari. Komsumsi tablet zat besi bersamaan dengan sayuran dan buah-buahan yang mengandung vitamin $\mathrm{C}$ dan tidak bersamaan dengan bahan makanan teh/ kopi karena dapat menghambat penyerapannya. (Kemenkes RI, 2013)

Tabel 3. Masalah lain yang berhubungan dengan kehamilan

\begin{tabular}{lcc}
\hline \multicolumn{1}{c}{ Masalah } & Frekuensi & Persentase \\
\hline Preeklampsi & 2 & 11,1 \\
Hiperemesis gravidarum & 1 & 5,5 \\
Gestasional diabetes & 3 & 16,6 \\
Gemelli/kehamilan & 1 & 5,5 \\
kembar & & \\
Letak sungsang & 4 & 22,3 \\
\hline
\end{tabular}

Sumber: Pengabdian kepada masyarakat tahun 2018

Kemungkinan terjadinya persalinan prematur dan berat badan lahir rendah meningkat pada ibu dengan preeklampsia. Ibu yang mengalami preeklampsia bisa tetap melahirkan bayi dengan sehat asalkan ditangani dengan cepat dan tepat. 
Risiko diabetes gestasional dapat terjadi selama kehamilan apabila memiliki indeks massa tubuh yang berlebihan sebelum kehamilan. Diabetes gestasional dapat mengakibatkan risiko persalinan prematur, tekanan darah tinggi dan preeklampsia. Kehamilan kembar dapat mempengaruhi kondisi fisik ibu selam kehamilan dan meningkatkan persalinan prematur. Pilihan persalinan harus dipertimbangkan dengan baik jika kondisi bayi sungsang tidak berubah hingga menjelang persalinan.

\section{SIMPULAN}

Kehamilan berisiko tinggi yang ditemukan pada pelaksanaan kegiatan meliputi paritas dibawah 20 tahun dan diatas 35 tahun, riwayat persalinan dengan sectio secarea, tinggi badan dibawah $145 \mathrm{~cm}$, preeklampsia, anemia, letak sungsang, hiperemesis gravidarum, gestasional diabetes, kehamilan kembar. Kegiatan skrining dan pengendalian faktor risiko kehamilan dengan pelayanan antenatal terpadu sangat diperlukan untuk mendeteksi secara dini kehamilan berisiko dan potensial mengalami kegawatdaruratan kehamilan. Selain skrining faktor risiko, tindakan pencegahan anemia defisiensi zat besi dapat dilakukan dengan pemberian tablet zat besi. KIE juga diberikan untuk meningkatkan pengetahuan ibu terkait pencegahan faktor risiko, pemenuhan kebutuhan dan mengatasi masalah kehamilan yang dialami ibu.

Dengan demikian diharapkan ibu hamil agar melakukan pemeriksaan kehamilan secara teratur agar mendapatkan informasi, dan pelayanan kesehatan sesuai kebutuhan ibu sehingga ibu hamil dapat melewati masa kehamilannya dengan baik dan menghasilkan bayi yang sehat dan berkualitas.

\section{UCAPAN TERIMAKASIH}

Puji dan syukur peneliti panjatkan kehadirat Tuhan yang Maha Pengasih yang melimpahkan karunia-Nya, sehingga kegiatan pengabdian kepada masyarakat ini dapat dilaksanakan. Dalam kesempatan ini penulis mengucapkan terimakasih kepada Ka.UPT Puskesmas Kecamatan Muara, dokter, bidan Desa Hutaginjang, kader dan semua pihak yang terkait dalam penelitian ini yang tidak dapat disebutkan satu persatu. Penulis menyadari masih banyak kekurangan dalam 
penyusunan penelitian ini maka saran dan kritik kami harapkan untuk kesempurnaan penelitian ini.

\section{DAFTAR PUSTAKA}

Kemenkes RI. (2013). Kehamilan, Persalinan, dan Nifas Normal. Buku Saku Pelayanan Kesehatan Ibu Di Fasilitas Kesehatan Dasar Dan Rujukan.

Kemenkes RI. (2014). Pelayanan Kesehatan Kehamilan. http://kesga.kemkes.go.id/images/pedoman/PMK PelayananKesehatan Kehamilan.pdf

Kemenkes RI. (2018). Profil Kesehatan Indonesia 2018 (Vol. 1227, Issue July). https://doi.org/10.1002/qj

Manuaba, IBG. (2014). Penyakit Kandungan dan KB Untuk Pendidikan Bidan. Ilmu Kebidanan.

Prawirohardjo, S. (2016). Ilmu Kebidanan Sarwono Prawirohardjo. Edisi Ke-4. Jakarta: Yayasan Bina Pustaka Sarwono Prawirohardjo. 